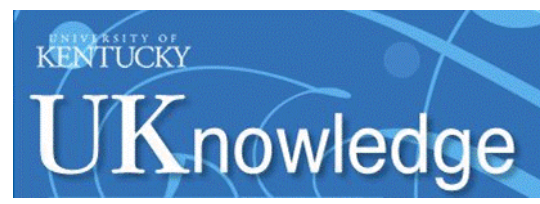

University of Kentucky

UKnowledge

8-2017

Increased Expression of M1 and M2 Phenotypic Markers in Isolated Microglia After Four-Day Binge Alcohol Exposure in Male Rats

Hui Peng

University of Kentucky, hui.peng@uky.edu

Chelsea Rhea Geil Nickell

University of Kentucky, chelsea.geil@uky.edu

Kevin Y. Chen

University of Kentucky, kevin.chen@uky.edu

Justin A. McClain

Gwynedd Mercy University

See next page for additional authors

Right click to open a feedback form in a new tab to let us know how this document benefits you. Follow this and additional works at: https://uknowledge.uky.edu/ps_facpub

Part of the Pharmacy and Pharmaceutical Sciences Commons, and the Substance Abuse and Addiction Commons 


\title{
Increased Expression of M1 and M2 Phenotypic Markers in Isolated Microglia After Four-Day Binge Alcohol Exposure in Male Rats
}

\author{
Digital Object Identifier (DOI) \\ https://doi.org/10.1016/j.alcohol.2017.02.175 \\ Notes/Citation Information \\ Published in Alcohol, v. 62, p. 29-40. \\ (C) 2017 Elsevier Inc. All rights reserved.
}

This manuscript version is made available under the CC-BY-NC-ND 4.0 license https://creativecommons.org/licenses/by-nc-nd/4.0/.

The document available for download is the author's post-peer-review final draft of the article.

\section{Authors}

Hui Peng, Chelsea Rhea Geil Nickell, Kevin Y. Chen, Justin A. McClain, and Kimberly Nixon 
Published in final edited form as:

Alcohol. 2017 August ; 62: 29-40. doi:10.1016/j.alcohol.2017.02.175.

\title{
Increased expression of M1 and M2 phenotypic markers in rats
}

\author{
Scienington, \\ KY 40536, USA
}

\section{Abstract} pathogenesis of AUDs. Therefore, male rats were gavaged with $25 \%$ (w/v) ethanol or isocaloric control diet every $8 \mathrm{~h}$ for 4 days and sacrificed at $0,2,4$, and 7 days after alcohol exposure (e.g. radient centrifugation. Cells were labeled with microglia surface antigens and analyzed by flow ticroglia M1 surface markers, major histocompatibility complex (MHC) II, CD32, CD86, and M2 surface and entorhinal cortices, while M2 marker, CD206, was increased significantly only in entorhinal hese findings that both pro-inflammatory and potentially beneficial, recovery-promoting important to our understanding of the role of microglia in the pathogenesis of AUDs.

\footnotetext{
*Corresponding author: Kimberly Nixon, Ph.D., University of Kentucky, Department of Pharmaceutical Sciences, 789 S. Limestone, TODD 473, Lexington, KY 40536, Telephone: +1 859218 1025, Fax: +1 859257 7585, kim-nixon@uky.edu.

${ }^{\dagger}$ Current address: Division of Natural and Computational Sciences, School of Arts and Sciences, Gwynedd Mercy University, 1325 Sumneytown Pike, Gwynedd Valley, PA 19437

Publisher's Disclaimer: This is a PDF file of an unedited manuscript that has been accepted for publication. As a service to our customers we are providing this early version of the manuscript. The manuscript will undergo copyediting, typesetting, and review of the resulting proof before it is published in its final citable form. Please note that during the production process errors may be discovered which could affect the content, and all legal disclaimers that apply to the journal pertain.
} 


\section{Keywords}

neuroinflammation; microglia; alcoholism; ethanol; neurodegeneration; flow cytometry

\section{Introduction}

According to new Diagnostic and Statistical Manual V criteria, an even larger portion of the U.S. population, nearly $14 \%$, meets the diagnostic criteria for an alcohol use disorder (AUD) in any given year (Grant et al., 2015). Excessive alcohol (ethanol) use, characteristic of an AUD, causes significant neuropathology throughout the brain, including the limbic system, cerebellum, and cerebral cortex, according to both human studies and animal models (Crews \& Nixon, 2009; de la Monte \& Kril, 2014; Sullivan \& Pfefferbaum, 2005). While human imaging studies have shown that both white and gray matter loss occurs in a variety of brain regions in alcoholics (Beresford et al., 2006; de la Monte \& Kril, 2014; Mechtcheriakov et al., 2007; Pfefferbaum et al., 1992; Sullivan \& Pfefferbaum, 2005), animal models of AUDs have been necessary to support the causal relationship between high blood alcohol concentrations characteristic of binge/bender pattern drinking and neurodegeneration (Collins, Corso, \& Neafsey, 1996; Crews, Braun, Hoplight, Switzer, \& Knapp, 2000; Crews \& Nixon, 2009; Hunt, 1993; Kelso, Liput, Eaves, \& Nixon, 2011). Binge drinking has been defined as imbibing 4 (women) or 5 (men) standard drinks within $2 \mathrm{~h}$ to produce blood ethanol concentrations (BECs) greater than $0.08 \mathrm{mg} / \mathrm{dL}$ (NIAAA; 2017), whereas a bender is repeated days of excessive intake including binge drinking. Over the last several years, studies have revealed that excessive alcohol exposure results in immune activation in the central nervous system (CNS), a phenomenon that several groups suggest is driving the pathogenesis of AUDs (Chastain \& Sarkar, 2014; Crews \& Vetreno, 2014; Cui, Shurtleff, \& Harris, 2014; Davis \& Syapin, 2004; Marshall et al., 2013; Vallés, Blanco, Pascual, \& Guerri, 2004).

Microglia are the myeloid-lineage, resident immune cells of the CNS that become activated in response to insult (Ransohoff \& Perry, 2009). Similar to what has been described in macrophages, microglia are often characterized as two distinct activated phenotypes: the M1 pro-inflammatory/classically activated phenotype, and the M2 anti-inflammatory/alternative activated phenotype (Benarroch, 2013; Beynon \& Walker, 2012; Carson et al., 2007; C. Colton \& Wilcock, 2010; Graeber, 2010; Raivich et al., 1999). While the M2 phenotypes promote tissue repair and phagocytosis of protein aggregates and cell debris, the M1 phenotypes are more likely to be detrimental to the brain by inducing neuronal toxicity through secretion of pro-inflammatory cytokine and chemokine and production of reactive oxygen species (ROS). Although we and others have documented the effect of ethanol on various neuroimmune activation markers and microglia in animal models of alcohol use and abuse (Alfonso-Loeches, Pascual-Lucas, Blanco, Sanchez-Vera, \& Guerri, 2010; Blednov et al., 2005; Crews, Zou, \& Qin, 2011; Fernandez-Lizarbe, Pascual, \& Guerri, 2009; Marshall et al., 2013; McClain et al., 2011; Nixon, Kim, Potts, He, \& Crews, 2008; Qin et al., 2008; Suk, 2007; Vallés et al., 2004), specific phenotypic M1 versus M2 markers have not been examined in the context of determining microglia phenotype. Therefore, the specific role of microglia in alcoholic neuropathology remains unclear. Identifying microglia activation 
states (phenotypes) is critical for understanding the role of microglia in the pathogenesis of AUDs.

Microglia are routinely enumerated and classified by morphology and cell-surface markers using immunohistochemistry, and indirectly through assessment of cytokine expression (though multiple cell types could be the source, such as astroglia; Bedi, Smith, Hetz, Xue, \& Cox, 2013; Beynon \& Walker, 2012; Colton \& Wilcock, 2010). For example, upregulation of ionized calcium binding adaptor molecule 1 (Iba-1) and monocyte chemotactic protein 1 (MCP1) immunoreactivity (He \& Crews, 2008) and observation of proliferating microglia (Dennis et al., 2013; Sutherland et al., 2013) in human alcoholic brain provide the most compelling evidence for at least some level of activation, but neither of these phenomena are associated specifically with an M1 state (Raivich et al., 1999). Our recent work using these two methodologies has shown that four-day binge alcohol exposure, a model of an AUD, shows that microglia are activated but potentially not to a classically activated or M1 phenotype (Marshall et al., 2013; McClain et al., 2011). However, the specific and wellaccepted phenotypic markers have not been examined. Therefore, the current study was designed to use Percoll separation/enrichment followed by three-color flow cytometric analysis of fluorescently labeled surface markers on microglia to enumerate microglia phenotypes from different brain regions, $48 \mathrm{~h}$ after four-day binge alcohol exposure. The fresh isolation of enriched cell suspensions enabled us to accurately quantify microglia activation states in entire populations of cells from regions of interest (hippocampus and entorhinal cortex) without reliance on manual morphometric counting of serial immunohistochemistry slides.

\section{Materials and Methods}

\section{Rat Model of an AUD}

All procedures were approved by the University of Kentucky Institutional Animal Care and Use Committee and adhered to the Guide for the Care and Use of Laboratory Animals (NRC, 1996). Thirty-three adult, male Sprague Dawley rats (275-300 g, Charles River Laboratories, Raleigh, NC) were pair-housed in a University of Kentucky AALAC accredited vivarium with a 12-h light:dark cycle. Rats were allowed to acclimate to the vivarium for 2 days followed by 3 days of handling before any experimentation. Except during the binge periods when chow was removed, animals had ad libitum access to food and water. Following acclimation, rats were gavaged with ethanol (25\% ethanol w/v in Vanilla Ensure Plus ${ }^{\circledR}$, Abbott Laboratories, Abbott Park, IL; $\mathrm{n}=17$ ) or isocaloric control diet (added dextrose; $\mathrm{n}=16$ ) every $8 \mathrm{~h}$ for 4 days following a procedure modified from Majchrowicz (1975), as reported previously (Morris, Kelso, Liput, Marshall, \& Nixon, 2010). Following an initial $5-\mathrm{g} / \mathrm{kg}$ ethanol dose, subsequent doses were titrated according to a 6-point intoxication behavior scale. BECs were determined in serum from tail blood collected 90 min following the seventh dose by an AM1 Alcohol Analyser (Analox, London, UK). Starting $10 \mathrm{~h}$ after the last dose of ethanol, withdrawal was observed for 30 min every $4 \mathrm{~h}$ for $16 \mathrm{~h}$. Behaviors were scored based on a scale modified from Majchrowicz (1975) but identical to that reported previously (Morris et al., 2010). 


\section{Isolation of microglia}

Microglia were isolated from brain tissue by Percoll gradient centrifugation as described previously (Frank, Wieseler-Frank, Watkins, \& Maier, 2006), with slight modification. Based on the time course of microglia activation in this model of an AUD, rats were humanely killed at 0, 2, 4, and 7 days following the last dose of ethanol (i.e., T0, T2, T4, and T7): rats were deeply anesthetized and transcardially perfused with $0.9 \% \mathrm{NaCl}$ containing heparin. Brains were harvested and the hippocampus and entorhinal cortex were dissected on ice. Tissue was finely minced with a razor blade and gently homogenized in Dulbecco's phosphate-buffered saline (DPBS), $\mathrm{pH} 7.4$, then passed through a 70- $\mu$ m nylon cell strainer (VWR, Batavia, IL). Resulting homogenates were centrifuged at $400 \times g$ for 6 min and cell pellets were resuspended in $2 \mathrm{~mL} 50 \%$ isotonic Percoll (GE Healthcare, Piscataway, NJ). Two milliliters of 50\% isotonic Percoll was gently layered on top of $1 \mathrm{~mL} \mathrm{70 \%} \mathrm{layer} \mathrm{and}$ then $1 \mathrm{~mL} 1 \times$ PBS was layered on top of the $50 \%$ Percoll layer. The density gradient was centrifuged at $1200 \times g$ for $45 \mathrm{~min}$ (minimum acceleration and brake) at $20{ }^{\circ} \mathrm{C}$. Microglia were collected from the interphase between the $70 \%$ and $50 \%$ isotonic Percoll phases (Frank et al., 2006). Cells were washed in $1 \times$ PBS and then resuspended in sterile DPBS.

\section{Microglia staining and flow cytometry}

Microglia were surface-stained with conjugated monoclonal antibodies to assess microglia purity (CD11b-FITC, BD Pharmingen, San Jose, CA; CD45-APC, eBioscience, San Diego, $\mathrm{CA}$ ) and M1 activation markers (CD86-PE, Fc $\gamma$ RIII[CD32]-PE, or MHC-II-PE, BD Pharmingen) as previous described (Bedi et al., 2013). For the M2 marker, microglia were stained with rabbit anti-rat CD206 (Abcam, Cambridge, MA), followed by a secondary incubation with donkey anti-rabbit-PE (BD Pharmingen). In brief, microglia were suspended in 50- $\mu \mathrm{L}$ incubation buffer ( $1 \times \mathrm{PBS}+0.1 \%$ bovine serum albumin) for $30 \mathrm{~min}$ on ice, and Fc receptors were blocked with anti-CD32 antibody (except for CD32 staining, eBioscience). Cells were incubated with antibodies for $30 \mathrm{~min}$ on ice in the dark. Cells were washed with $1 \times$ PBS and fixed with a formaldehyde-based fixation buffer (eBioscience $\# 00-8222)$ on ice.

Data were acquired with an Attune Acoustic Focusing Cytometer (ABI, Carlsbad, CA) and analyzed with Attune Acoustic software (ABI). Before each run, the cytometer was calibrated with commercially available beads. Fluorescence spillover compensation values were generated using pooled non-stained cells and single-color staining as a control. Debris and aggregates were eliminated from the analysis by forward- and side-scatter characteristics. Myeloid cells identified as $\mathrm{CD} 11 \mathrm{~b}^{+}$cells were divided into CD45 low microglia and a small CD45 ${ }^{\text {high }}$ subpopulation (Fig. 1A). Polarization states of $\mathrm{CD} 11 \mathrm{~b}^{+} \mathrm{CD} 45^{\text {low }}$ microglia were evaluated for expression of M1 markers CD32, CD86, or MHC-II and M2 marker, CD206 (Fig. 3A, Figs. 3-6). For each sample, approximately 10,000 singlets were analyzed.

\section{Statistical analysis}

All values are represented as mean \pm SEM. To verify that alcohol exposure between time point groups was relatively similar, subject data of BEC and mean dose per day were analyzed by one-way ANOVA. As the primary question of interest in these studies is 
whether the ethanol group differed from controls at each time point, planned comparisons were performed. Therefore, all comparisons were two-factors, control versus ethanol groups at each time point, and conducted via $t$ tests. A $p$ value $<0.05$ was accepted as statistically significant.

\section{Results \\ Binge data}

During four days of alcohol exposure, rats received an overall mean dose of $9.9 \pm 0.7$ $\mathrm{g} / \mathrm{kg} /$ day of ethanol, which produced a peak blood ethanol concentration of $396.1 \pm 82.5$ $\mathrm{mg} / \mathrm{dL}$, measured at the third day of exposure. Subject data for each time point are shown in Table 1, and are generally similar between groups with the exception of the T0 BEC, which was significantly less than other time points $\left(F_{(3,12)}=17.65, p<0.05\right)$. All other parameters are similar between time points. BEC is higher than that observed with the same model historically in the laboratory. However, the range of BEC values and the mean dose per day are remarkably similar to that reported previously (Marshall et al., 2013; Morris et al., 2010).

\section{Small CD45hi myeloid population increased after four-day binge}

Myeloid cells were isolated from the hippocampus and entorhinal cortex at 0, 2, 4, and 7 days after alcohol exposure. These time points were selected based on our previous observations of microglial activation according to PK-11195 receptor autoradiography, microglia morphological change, and expression of cytokines in four-day binge ethanolexposed rats versus controls at these times (Marshall et al., 2013). A simple mechanical dissociation was chosen to homogenize CNS tissue versus using an enzymatic digestion procedure in order to better preserve the immunophenotype of microglia and macrophages. Percoll-isolated cells were stained for CD11b (a component of complement receptor 3), which is constitutively expressed by microglia and macrophages and thus can be used to determine cell purity. Consistent with prior studies, isolated cells yielded highly enriched microglia and macrophages for immediate functional characterization ex vivo (Frank et al., 2006): over $95 \%$ pure as evidenced by staining for the microglia and macrophage antigen CD11b (Fig. 1A).

$\mathrm{CD} 11 \mathrm{~b}+$ myeloid cells were further divided into microglia $\left(\mathrm{CD} 11 \mathrm{~b}^{+} \mathrm{CD} 45^{\text {low }}\right)$ and a small population of $\mathrm{CD} 11 \mathrm{~b}^{+} \mathrm{CD} 45^{\text {high }}$ cells based on their CD45 expression (Bedi et al., 2013). $\mathrm{CD} 11 \mathrm{~b}^{+} \mathrm{CD} 45^{\text {high }}$ cells have been described as endogenous CNS macrophages in a noninflammatory context (Ford, Goodsall, Hickey, \& Sedgwick, 1995) or as a combination of infiltrating monocytes/macrophages, neutrophils, and activated CNS microglia/macrophages in CNS injury scenarios (Jin, Ishii, Bai, Itokazu, \& Yamashita, 2012; Stirling \& Yong, 2008). We observed a small population of $\mathrm{CD} 11 \mathrm{~b}^{+} \mathrm{CD} 45^{\text {high }}$ in hippocampus and entorhinal cortex of both control and alcohol-exposed rats. The frequency of these cells increased significantly in alcohol-exposed groups $(3.42 \% \pm 1.35$ at $\mathrm{T} 0,4.64 \% \pm 1.00$ at $\mathrm{T} 2)$ versus controls $(1.25 \% \pm 0.42$ at $\mathrm{T} 0,1.35 \% \pm 0.36$ at $\mathrm{T} 2)$ in hippocampus as well as in the entorhinal cortex in alcohol-exposed rats $(2.28 \% \pm 0.62$ at $\mathrm{T} 0,6.85 \% \pm 3.49$ at $\mathrm{T} 2)$ versus controls $(1.51 \% \pm 0.64$ at $\mathrm{T} 0,1.57 \% \pm 0.40$ at $\mathrm{T} 2)$, while complementary changes in 
frequency of the majority $\mathrm{CD} 11 \mathrm{~b}^{+} \mathrm{CD} 45^{\text {low }}$ microglial population were also noted in hippocampus at $\mathrm{T} 2(80.87 \% \pm 7.88$ in alcohol-exposed rats versus $93.02 \% \pm 2.05$ in control rats) and entorhinal cortex at $\mathrm{T} 2(84.24 \% \pm 6.98$ in alcohol-exposed rats versus $92.74 \%$ \pm 0.89 in control rats).

CD11b is constitutively expressed by microglia, though expression increases with microglia activation (Hynes, 1992; Marshall et al., 2013; Morioka, Kalehua, \& Streit, 1992). Four-day binge alcohol exposure significantly increased the expression of $\mathrm{CD} 11 \mathrm{~b}$ on $\mathrm{CD} 11 \mathrm{~b}^{+} \mathrm{CD} 45^{\text {low }}$ microglia in both hippocampus (Fig. 2A) and entorhinal cortex (Fig. 2B) at T2. Alcohol exposure also increased CD45 expression on microglia in both hippocampus (Fig. 2C) and entorhinal cortex (Fig. 2D) at T0, with the most dramatic changes at the T2 time point, all of which resolved to control levels by $\mathrm{T} 4$.

\section{Increased expression of neuroimmune activation markers on the surface of microglia after four-day binge alcohol exposure}

Activated microglia can be classified as either M1 or M2 based on morphology and/or cell surface antigens (Beynon \& Walker, 2012; Colton \& Wilcock, 2010; Ransohoff \& Perry, 2009). Markers such as major histocompatibility complex (MHC) II, CD86, CD16/32, and iNOS have been used to identify M1-polarized cells (David \& Kroner, 2011). M2 microglia, however, express the macrophage mannose receptor 1 (MMR, or CD206) on the cell membrane and Arginase-1, a prototypical M2 marker, intracellularly (Graeber, 2010; Nimmerjahn, Kirchhoff, \& Helmchen, 2005). To assess global microglia/macrophage activation states after four-day binge alcohol exposure, we isolated myeloid cells from the hippocampus and the entorhinal cortices at T0, T2, T4, and T7 days after alcohol exposure. To characterize the activation profile of microglia (CD45 ${ }^{\text {low }}$ ) and CNS macrophages (CD45 ${ }^{\text {high }}$ ) after alcohol exposure, these cells were analyzed for several M1 (MHC-II and CD86, CD32) and M2 (CD206) surface markers (Fig. 3A).

Two markers involved in antigen presentation, MHC-II and CD86, were identified on both $\mathrm{CD} 11 \mathrm{~b}^{+} \mathrm{CD} 45^{\text {low }}$ microglia and $\mathrm{CD} 11 \mathrm{~b}^{+} \mathrm{CD} 45^{\mathrm{hi}}$ cell populations (Fig. 3A). For MHC-II, as expected, the majority of microglia $\left(\mathrm{CD} 11 \mathrm{~b}^{+} \mathrm{CD} 45^{\text {low }}\right)$ were negative for MHC-II expression. After four-day binge alcohol exposure, the frequency of the MHC-II ${ }^{+}$cells increased slightly but not significantly in both hippocampus and entorhinal cortex at T0 ( $p=$ n.s.), with significant changes at the T2 time point (Fig. $3 ; p<0.05$ ). At T2, we observed increased expression of $\mathrm{MHC}-\mathrm{II}^{+}$cells in the hippocampus (2.73\% in control rats to $11.28 \%$ in ethanol-exposed rats; $p=0.009$, Fig. 3B) and in the entorhinal cortex ( $2.19 \%$ in control rats to $11.52 \%$ in ethanol-exposed rats; $p=0.009$, Fig. $3 \mathrm{C}$ ), all of which resolved to control levels by $\mathrm{T} 4$. The overall expression of MHC-II on CD11 b ${ }^{+} \mathrm{CD} 45^{\text {high }}$ cells (macrophages or neutrophils) is much higher than on $\mathrm{CD} 11 \mathrm{~b}^{+} \mathrm{CD} 45^{\text {low }}$ microglia. Ethanol exposure does not affect the expression of MHC-II in the CD11 $\mathrm{b}^{+} \mathrm{CD} 45^{\text {high }}$ cell population (Fig. 3D \& E).

For CD86 expression, the majority of microglia $\left(\mathrm{CD} 11 \mathrm{~b}^{+} \mathrm{CD} 45^{\text {low }}\right)$ were negative for $\mathrm{CD} 86$ expression (Fig. 4). After four-day binge alcohol exposure, the frequency of the CD86 ${ }^{+}$cells in microglia increased slightly at T0 ( $p=$ n.s.) only in entorhinal cortex (Fig. 4B), with the most dramatic changes at the $\mathrm{T} 2$ time point in both hippocampus and entorhinal cortex (Fig. 4). At $\mathrm{T} 2$, we observed increased expression of $\mathrm{CD} 86^{+}$cells in the hippocampus $(3.16 \%$ in 
control rats to $9.14 \%$ in ethanol-exposed rats; $p=0.011$, Fig. 4A), and in the entorhinal cortex (2.48\% in control rats to $9.23 \%$ in ethanol-exposed rats; $p=0.001$, Fig. 4B), all of which resolved to control levels by $\mathrm{T} 4$. The overall expression of CD86 in CD11b ${ }^{+} \mathrm{CD} 45^{\text {high }}$ cells is much higher than $\mathrm{CD} 11 \mathrm{~b}^{+} \mathrm{CD} 45^{\text {low }}$ microglia (Fig. $4 \mathrm{C} \& \mathrm{D}$ ). Ethanol exposure increased the expression frequency of $\mathrm{CD} 86$ in the $\mathrm{CD} 11 \mathrm{~b}^{+} \mathrm{CD} 45^{\text {high }}$ cell population in entorhinal cortex from $22.49 \%$ to $32.58 \%$ ( $p=0.04$ ).

While the functional role of the $\mathrm{Fc} \gamma$ receptors on microglia remains to be illuminated, CD16/32 has been widely used as an M1 marker in the CNS (Bedi et al., 2013; Kigerl et al., 2009). For CD32 (Fc $\gamma$ RIII) expression, results showed that after four-day binge alcohol exposure, the frequency of the $\mathrm{CD} 32^{+}$cells in $\mathrm{CD} 11 \mathrm{~b}^{+} \mathrm{CD} 45^{\text {low }}$ microglia increased slightly at T0 ( $p=$ n.s.), with the most dramatic changes at the T2 time point (Fig. 5). At T2, we observed increased expression of CD32+ cells in the hippocampus $(16.16 \%$ in control rats to $41.56 \%$ in ethanol-exposed rats; $p=0.01$, Fig. $5 \mathrm{~A})$, and in the entorhinal cortex $(21.07 \%$ in control rats to $47.74 \%$ in ethanol-exposed rats; $p=0.004$, Fig. $5 \mathrm{~B}$ ). Although there was an increased frequency of $\mathrm{CD} 32+$ cells in $\mathrm{CD} 11 \mathrm{~b}^{+} \mathrm{CD} 45^{\text {low }}$ microglia at $\mathrm{T} 4$ (from $21.55 \%$ in control rats to $33.66 \%$ in ethanol-exposed rats), it was not significant in hippocampus ( $p=$ 0.20 ; Fig. 5A), though there was a solid trend in entorhinal cortex (from $18.32 \%$ in control rats to $38.51 \%$ in ethanol-exposed rats; $p=0.055$, Fig. $5 \mathrm{~B}$ ). The levels in ethanol-exposed rats were identical to the levels in control rats by $\mathrm{T} 7$. The overall expression of $\mathrm{CD} 32$ on $\mathrm{CD} 11 \mathrm{~b}^{+} \mathrm{CD} 45^{\text {high }}$ cells is much higher than on $\mathrm{CD} 11 \mathrm{~b}^{+} \mathrm{CD} 45^{\text {low }}$ microglia (Fig. 5C \& D). Ethanol exposure increased the expression frequency of CD32 in CD11b ${ }^{+} \mathrm{CD} 45^{\text {high }}$ cell population in entorhinal cortex (from $49.47 \%$ to $69.21 \%, p=0.035$ ).

CD206, macrophage mannose receptor 1 , is the prototypical anti-inflammatory surface marker and has been used to identify M2 microglia in other CNS insults (Bedi et al., 2013; Beynon \& Walker, 2012; Cherry, Olschowka, \& O'Banion, 2014; Kigerl et al., 2009). In this study, it was used to evaluate the M2 marker expression on microglia/macrophages following alcohol exposure. The results showed that after four-day binge alcohol exposure, the frequency of $\mathrm{CD} 206^{+}$cells in $\mathrm{CD} 11 \mathrm{~b}^{+} \mathrm{CD} 45^{\text {low }}$ microglia in the hippocampus increased at the T2 time point, from $1.55 \%$ in control rats to $16.94 \%$ in ethanol-exposed rats, $(p=$ 0.105 , Fig. 6A), and in the entorhinal cortex from $1.97 \%$ to $15.81 \%$ ( $p=0.007$, Fig. 6B), all of which resolved to control levels by T4. The overall expression of CD206 on $\mathrm{CD} 11 \mathrm{~b}^{+} \mathrm{CD} 45^{\text {high }}$ cells is much higher than on $\mathrm{CD} 11 \mathrm{~b}^{+} \mathrm{CD} 45^{\text {low }}$ microglia (Fig. 6). Ethanol exposure did not affect the expression of $\mathrm{CD} 206$ on the $\mathrm{CD} 11 \mathrm{~b}^{+} \mathrm{CD} 45^{\text {high }}$ cell population (Fig. 6C \& D).

\section{Discussion}

In this study, Percoll gradient centrifugation was used to isolate myeloid cells, followed by flow cytometric methods to evaluate the activation state (phenotype) of the macrophage/ microglia population in the hippocampus and entorhinal cortex in a four-day binge model of an AUD. To our knowledge, this is the first report using these combined methodologies to identify microglia phenotype within the alcohol research field. By using monoclonal antibodies against surface antigens to identify macrophages/microglia and characterize their polarization state, we found that alcohol exposure induces a significant increase of both 
classically activated M1 and alternatively activated M2 microglia in hippocampus and entorhinal cortex after four-day binge alcohol exposure, with the most extensive changes at T2. This method has been shown to provide reproducible, sensitive, and quantitative measurement of microglia phenotypes in whole brain and/or brain regions of interest (Frank et al., 2006).

For cell isolation, we used mechanical dissociation of tissue followed by Percoll density gradient centrifugation to rapidly isolate microglia and macrophages from brain tissue. This non-enzymatic procedure allowed for the characterization of the cells without concern that their surface features had been enzymatically altered during tissue processing (Frank et al., 2006). This well-tested method has proven to be a powerful tool to study basic microglia biology and microglia immunophenotype and/or activation state under pathological conditions. The isolated cell population is not only sufficiently enriched with microglia and macrophages while excluding other cell types such as astrocytes, but these microglia/ macrophages also maintain their functional responsiveness after isolation (Barrientos et al., 2015; Frank, Baratta, Sprunger, Watkins, \& Maier, 2007; Frank et al., 2006). Consistent with prior studies, our analysis revealed that purity and enrichment efficiency of myeloid cell suspensions yields over 95\% CD11b+ cells (Fig. 1). Quiescent microglia typically display an MHC II-negative and CD86-negative immunophenotype (Colton \& Wilcock, 2010; Frank et al., 2006; Guillemin \& Brew, 2004). Flow cytometric analysis of isolated microglia from control rat brain also demonstrated that MHC II and CD86 expression was very low in control conditions (less than 3\%), which provides additional evidence that the isolation procedure preserves the in situ activation state of microglia. One potential limitation of the study is that we used an anti-CD32 antibody to block Fc-mediated non-specific antibody binding instead of an isotype control (an antibody raised against an antigen not present on the cell type being analyzed). An isotype control will determine the non-specific binding of antibody to Fc receptors and ensure the observed staining is due to specific binding rather than an artifact. Our choice of the $\mathrm{Fc}$ receptor antibody to block nonspecific binding is common in studies with multiple antibodies used. To further reduce non-specific antibody binding, we also added bovine serum albumin to the staining buffer and titrated the antibody concentrations. Both the M1 and M2 marker expression is low in the control animals, which suggests that the background expression of these antibodies is very low. Without an isotype control, we cannot fully determine the background of our antibodies used, but the results generated from control and ethanol groups give us the relative quantification of the marker expression between control and ethanol-exposure groups.

Traditionally, the CNS has been described as an immune-privileged site, where the blood brain barrier limits movement of peripheral immune cells into the CNS. However, the blood brain barrier may be compromised by excessive alcohol consumption and become more permissive to immune cell extravagation (Alikunju, Abdul Muneer, Zhang, Szlachetka, \& Haorah, 2011; Haorah, Knipe, Leibhart, Ghorpade, \& Persidsky, 2005). Although there is no evidence of blood brain barrier compromise in the four-day binge model used (Marshall et al., 2013), a small population of $\mathrm{CD} 11 \mathrm{~b}^{+} \mathrm{CD} 45^{\text {high }}$ cells was observed in both the hippocampus and entorhinal cortex, and the frequency of these cells increased in the ethanol-exposed group versus control animals (Fig. 1B \& C). These cells displayed higher mean intensity values of CD11b and CD45 (Fig. 2) and a higher percentage of $\mathrm{MHC}-\mathrm{II}^{+} /$ 
$\mathrm{CD} 6^{+} / \mathrm{CD} 32^{+} / \mathrm{CD} 206$ staining than the CD $45^{\text {low }}$ microglial population (Figs. 3-6). $\mathrm{CD} 11 \mathrm{~b}^{+} \mathrm{CD} 45^{\text {high }}$ cells have been described as endogenous CNS macrophages in a noninflammatory context (Ford et al., 1995). In injured brains, CD11b ${ }^{+} \mathrm{CD} 45^{\text {high }}$ cells are likely a mixed population of inflammatory myeloid cell types, such as infiltrating monocyte/ macrophages, activated CNS microglia/macrophages, and possibly a few dendritic cells and neutrophils (Bedi et al., 2013). To further discriminate neutrophils from microglia/ macrophages, a neutrophil marker such as Gr-1 could be used to eliminate neutrophils from this population before analysis.

Phenotypic markers such as MHC-II, CD86, iNOS, and CD16/32 have been used widely to identify M1-polarized cells (David \& Kroner, 2011; Kigerl et al., 2009; Ponomarev, Veremeyko, Barteneva, Krichevsky, \& Weiner, 2011), while CD206 (MMR) and arginase-1 have been used to differentiate M2 microglia (Graeber, 2010; Kigerl et al., 2009; Nimmerjahn et al., 2005). In this study, we chose to examine surface markers (MHC-II, CD86, CD32, and CD206) versus the intracellular markers (such as iNOS and arginase-1) to avoid permeabilization for intracellular staining to retain ability to sort live cells for future functional experiments. Although the heterogeneity of microglia has been well described in other neuroinflammatory diseases (Carson et al., 2007; Colton et al., 2006; Kigerl et al., 2009; Mikita et al., 2011; Zhang \& Gensel, 2014), we are the first to identify various phenotypes of microglia under alcohol exposure using flow cytometric analysis of M1 and M2 surface markers. Our results show that four-day binge alcohol exposure induced a transient increase of classically activated M1 microglia (as indicated by the increased expression of MHC-II, CD86, and CD32), as well as alternatively activated M2 microglia as indicated by the increased expression of CD206.

Evidence that ethanol activates microglia to a pro-inflammatory stage has emerged from several studies showing increased expression of pro-inflammatory cytokines, chemokines, and danger-associated molecular patterns (DAMPs) in human alcoholic brain as well as in rodent models of AUDs (Antón et al., 2016; Blednov et al., 2012; Crews, Qin, Sheedy, Vetreno, \& Zou, 2013; Flatscher-Bader et al., 2005; Liu et al., 2006; Vetreno \& Crews, 2012; Vetreno, Qin, \& Crews, 2013; Wang et al., 2015; see also Crews et al., 2006; Crews \& Vetreno, 2014; Robinson et al., 2014 for review). For example, chronic alcohol exposure induces microglia expression of pro-inflammatory factors, including TNF- $\alpha$, IL-1 $\beta$, and IL-6 (Boyadjieva \& Sarkar, 2010; Fernandez-Lizarbe, Montesinos, \& Guerri, 2013), factors that are associated with alcohol drinking and preference (Bajo et al., 2014; Blednov et al., 2012; Robinson et al., 2014). Intermittent exposure to alcohol in rodent models activates microglia and stimulates production of pro-inflammatory and neurotoxic molecules including NO and COX2, cytokines such as TNF- $\alpha$ and IL- $1 \beta$, and chemokines including MCP1 and MIP-1 $a$ and $\beta$ (Alfonso-Loeches et al., 2010; Blanco \& Guerri, 2007; He \& Crews, 2008; Pascual, Blanco, Cauli, Miñarro, \& Guerri, 2007; Qin et al., 2008; Vallés et al., 2004). In adult mice, chronic ethanol administration increases TNF-a levels in the brain and potentiates the LPS-induced increase in IL-1 $\beta$ levels in the brain (Qin et al., 2008). Some of the most compelling data for a role of innate immune activation in AUDs come from evidence of increased DAMP signaling, specifically high mobility group box 1 (HMGB1), which is evident in human brain tissue as well as animal models (Antón et al., 2016; Crews et al., 2013; Vetreno \& Crews, 2012; Vetreno et al., 2013; Wang et al., 2015). The increased 
expression of pro-inflammatory markers in these published studies supports the increase in M1 phenotypic markers observed here (Figs. 3-5). The microglia morphological changes were most robust on $\mathrm{T} 2$, which is also consistent with the increase in M1 marker expression as well as the timeline of the acute phase of neuroinflammation following brain injury (Ansari, 2015; Bedi et al., 2013; Ransohoff \& Perry, 2009). Indeed, the relatively few effects at T0 may be due, in part, to blunted immune and/or neuroimmune function during ethanol intoxication (Aroor \& Baker, 1998; Gano, Doremus-Fitzwater, \& Deak, 2016; Goral, Karavitis, \& Kovacs, 2008). Intriguingly, however, our previous studies showed that the same AUD model as used in the current experiments results in morphological changes in microglia consistent with activation (cellular processes become shorter, broader, and less branched while the somas exhibited hypertrophy), but without the induction of proinflammatory cytokines in entorhinal cortex or hippocampus (Marshall et al., 2013; McClain et al., 2011), an observation confirmed by others (Zahr, Luong, Sullivan, \& Pfefferbaum, 2010). Thus, based on the morphological, immunohistochemical, and ELISA data in these reports, we concluded that microglia activation in this model was not pro-inflammatory (Marshall et al., 2013). While the immunohistochemical approaches are necessary for the assessment of cell morphology, flow cytometric analysis of the Percoll-enriched microglia reveals the global activation state of the entire microglial population of the region examined. For example, the increased expression of MHC-II in the current experiment was not expected based on negative MHC-II immunohistochemistry in our prior report (Marshall et al., 2013). However, immunohistochemistry is performed on only one out of every 12 brain sections, which makes it theoretically possible that MHC-II+ cells could be missed, especially if they were localized to a particular, small region (e.g., Ward et al., 2009). Therefore, the flow cytometric technique used in these studies is proving to be a more sensitive and quantitative measure, which may provide a more accurate characterization of an entire cell population (Bedi et al., 2013; Ransohoff \& Perry, 2009). Although the observation of increased M1-like marker expression may appear contradictory, the ratio of M1 to M2 microglia would better define the contribution of these different phenotypes to the pro- or anti-inflammatory environment.

The increase in M2 marker, CD206, was predicted by our previous work and hypotheses that beneficial microglia may underlie plasticity and reparative responses following alcohol insult (Marshall et al., 2013; McClain et al., 2011). Multiple approaches immunohistochemistry, morphology, and ELISAs of anti-inflammatory cytokines and growth factors - supported the conclusion that microglia after four-day binge alcohol exposure may be of the beneficial phenotype (Marshall et al., 2013; McClain et al., 2011). Indeed, the fold change in the percentage of $\mathrm{CD} 11 \mathrm{~b}+/ \mathrm{CD} 45^{\text {lo }}$ cells expressing CD206 is quite striking. When the current data are considered with our past work, namely ELISAs that consistently show increases in anti-inflammatory cytokine and growth factor expression, the data herein continue to support our hypothesis that microglia are of a beneficial phenotype. The finding of M2-type of microglia, however, is not inconsistent with innate immune induction via DAMPs eliciting primed microglia (Crews et al., 2013; Frank et al., 2016; Weber, Frank, Tracey, Watkins, \& Maier, 2015). There is significant overlap between M2like marker expression and primed microglia (Perry \& Holmes, 2014; Ransohoff \& Perry, 2009), and past work supports the idea that alcohol primes microglia (e.g., Qin et al., 2008), 
including in the 4-day binge model (Marshall, Geil, \& Nixon, 2016). Therefore, development of potential therapeutics that target microglia will need to be more specific than merely "inhibiting microglial activation". Ablating all microglia is often detrimental to brain recovery processes, which supports the conclusion that maintaining some microglia homeostatic functions or perhaps promoting the M2, reparative population, is necessary for plasticity and regenerative mechanisms (Cherry et al., 2014; Colton, 2009; LalancetteHebert, Gowing, Simard, Weng, \& Kriz, 2007; Szalay et al., 2016; Yenari, Kauppinen, \& Swanson, 2010). Therapeutic approaches that induce M2 polarization or specifically inhibit the pathological or chronic M1-like responses may be indicated. It is important to note, though, that some neuroimmune activation is necessary and perhaps beneficial; some TNF-a induction is required to elicit protective M2 responses (e.g., Lambertsen et al., 2009; Turrin \& Rivest, 2006). It is possible that the increase in M1 markers reflects that point.

Microglia activation is a dynamic process that generates complex, overlapping patterns of surface marker expression in various neurodegenerative disease models (e.g., Hu et al., 2012; Kigerl et al., 2009) and, as we now describe, for a model of an AUD as well. Reproducible, quantitative measurement of microglia phenotypes in whole brains and/or regions of interest have made important contributions to our understanding of microglial biology in models of neurodegenerative and psychological diseases such as AUDs. This novel result of increased M2-like cells is critical to our understanding of the role of microglia in the development of and recovery from AUDs. Most especially, these data are important because microglial activation is an emerging therapeutic target for antiinflammatory strategies in neurodegenerative disorders and CNS insults, including AUDs (Crews \& Vetreno, 2014; Crews et al., 2011; Cui et al., 2014). It is critical to understand the phenotype of microglia induced by an insult in order to develop therapies specifically targeting pathological aspects of the neuroimmune response, likely the chronic proinflammatory M1 response, while maintaining or promoting beneficial M2 responses. As microglia phenotype has not been considered in the context of the pathogenesis of AUDs, these findings have important implications for drug discovery efforts on the pharmacotherapeutic treatment of AUDs.

\section{Acknowledgments}

This work was funded by National Institutes of Health grants R01AA016959 (KN), F31AA023459 (CRGN) and R03NS089433 (HP), T32 DA016176 (CRGN, JAM), University of Kentucky Center for Drug \& Alcohol Research (pilot project to JAM) and the University of Kentucky Department of Pharmaceutical Sciences.

\section{References}

Alfonso-Loeches S, Pascual-Lucas M, Blanco AM, Sanchez-Vera I, Guerri C. Pivotal role of TLR4 receptors in alcohol-induced neuroinflammation and brain damage. The Journal of Neuroscience. 2010; 30:8285-8295. DOI: 10.1523/JNEUROSCI.0976-10.2010 [PubMed: 20554880]

Alikunju S, Abdul Muneer PM, Zhang Y, Szlachetka AM, Haorah J. The inflammatory footprints of alcohol-induced oxidative damage in neurovascular components. Brain, Behavior, and Immunity. 2011; 25(Suppl 1):S129-136. DOI: 10.1016/j.bbi.2011.01.007

Ansari MA. Temporal profile of M1 and M2 responses in the hippocampus following early $24 \mathrm{~h}$ of neurotrauma. Journal of the Neurological Sciences. 2015; 357:41-49. DOI: 10.1016/j.jns. 2015.06.062 [PubMed: 26148932] 
Antón M, Alén F, Gómez de Heras R, Serrano A, Pavón FJ, Leza JC, et al. Oleoylethanolamide prevents neuroimmune HMGB1/TLR4/NF-kB danger signaling in rat frontal cortex and depressivelike behavior induced by ethanol binge administration. Addiction Biology. 2016; 22:724-741. DOI: 10.1111/adb.12365 [PubMed: 26857094]

Aroor AR, Baker RC. Ethanol inhibition of phagocytosis and superoxide anion production by microglia. Alcohol. 1998; 15:277-280. [PubMed: 9590511]

Bajo M, Madamba SG, Roberto M, Blednov YA, Sagi VN, Roberts E, et al. Innate immune factors modulate ethanol interaction with GABAergic transmission in mouse central amygdala. Brain, Behavior, and Immunity. 2014; 40:191-202. DOI: 10.1016/j.bbi.2014.03.007

Barrientos RM, Thompson VM, Kitt MM, Amat J, Hale MW, Frank MG, et al. Greater glucocorticoid receptor activation in hippocampus of aged rats sensitizes microglia. Neurobiology of Aging. 2015; 36:1483-1495. DOI: 10.1016/j.neurobiolaging.2014.12.003 [PubMed: 25559333]

Bedi SS, Smith P, Hetz RA, Xue H, Cox CS. Immunomagnetic enrichment and flow cytometric characterization of mouse microglia. Journal of Neuroscience Methods. 2013; 219:176-182. DOI: 10.1016/j.jneumeth.2013.07.017 [PubMed: 23928152]

Benarroch EE. Microglia: Multiple roles in surveillance, circuit shaping, and response to injury. Neurology. 2013; 81:1079-1088. DOI: 10.1212/WNL.0b013e3182a4a577 [PubMed: 23946308]

Beresford TP, Arciniegas DB, Alfers J, Clapp L, Martin B, Du Y, et al. Hippocampus volume loss due to chronic heavy drinking. Alcoholism: Clinical and Experimental Research. 2006; 30:1866-1870. DOI: 10.1111/j.1530-0277.2006.00223.x

Beynon SB, Walker FR. Microglial activation in the injured and healthy brain: what are we really talking about? Practical and theoretical issues associated with the measurement of changes in microglial morphology. Neuroscience. 2012; 225:162-171. DOI: 10.1016/j.neuroscience. 2012.07.029 [PubMed: 22824429]

Blanco AM, Guerri C. Ethanol intake enhances inflammatory mediators in brain: role of glial cells and TLR4/IL-1RI receptors. Frontiers in Bioscience. 2007; 12:2616-2630. [PubMed: 17127267]

Blednov YA, Bergeson SE, Walker D, Ferreira VM, Kuziel WA, Harris RA. Perturbation of chemokine networks by gene deletion alters the reinforcing actions of ethanol. Behavioural Brain Research. 2005; 165:110-125. DOI: 10.1016/j.bbr.2005.06.026 [PubMed: 16105698]

Blednov YA, Ponomarev I, Geil C, Bergeson S, Koob GF, Harris RA. Neuroimmune regulation of alcohol consumption: behavioral validation of genes obtained from genomic studies. Addiction Biology. 2012; 17:108-120. DOI: 10.1111/j.1369-1600.2010.00284.x [PubMed: 21309947]

Boyadjieva NI, Sarkar DK. Role of microglia in ethanol's apoptotic action on hypothalamic neuronal cells in primary cultures. Alcoholism: Clinical and Experimental Research. 2010; 34:1835-1842. DOI: 10.1111/j.1530-0277.2010.01271.x

Carson MJ, Bilousova TV, Puntambekar SS, Melchior B, Doose JM, Ethell IM. A rose by any other name? The potential consequences of microglial heterogeneity during CNS health and disease. Neurotherapeutics. 2007; 4:571-579. DOI: 10.1016/j.nurt.2007.07.002 [PubMed: 17920538]

Chastain LG, Sarkar DK. Role of microglia in regulation of ethanol neurotoxic action. International Review of Neurobiology. 2014; 118:81-103. DOI: 10.1016/B978-0-12-801284-0.00004-X [PubMed: 25175862]

Cherry JD, Olschowka JA, O'Banion MK. Neuroinflammation and M2 microglia: the good, the bad, and the inflamed. Journal of Neuroinflammation. 2014; 11:98.doi: 10.1186/1742-2094-11-98 [PubMed: 24889886]

Collins MA, Corso TD, Neafsey EJ. Neuronal degeneration in rat cerebrocortical and olfactory regions during subchronic "binge" intoxication with ethanol: possible explanation for olfactory deficits in alcoholics. Alcoholism: Clinical and Experimental Research. 1996; 20:284-292.

Colton C, Wilcock DM. Assessing activation states in microglia. CNS \& Neurological Disorders Drug Targets. 2010; 9:174-191. [PubMed: 20205642]

Colton CA. Heterogeneity of microglial activation in the innate immune response in the brain. Journal of Neuroimmune Pharmacology. 2009; 4:399-418. DOI: 10.1007/s11481-009-9164-4 [PubMed: 19655259] 
Colton CA, Mott RT, Sharpe H, Xu Q, Van Nostrand WE, Vitek MP. Expression profiles for macrophage alternative activation genes in $\mathrm{AD}$ and in mouse models of $\mathrm{AD}$. Journal of Neuroinflammation. 2006; 3:27.doi: 10.1186/1742-2094-3-27 [PubMed: 17005052]

Crews FT, Bechara R, Brown LA, Guidot DM, Mandrekar P, Oak S, et al. Cytokines and alcohol. Alcoholism: Clinical and Experimental Research. 2006; 30:720-730. DOI: 10.1111/j. 1530-0277.2006.00084.x

Crews FT, Braun CJ, Hoplight B, Switzer RC 3rd, Knapp DJ. Binge ethanol consumption causes differential brain damage in young adolescent rats compared with adult rats. Alcoholism: Clinical and Experimental Research. 2000; 24:1712-1723.

Crews FT, Nixon K. Mechanisms of neurodegeneration and regeneration in alcoholism. Alcohol and Alcoholism. 2009; 44:115-127. DOI: 10.1093/alcalc/agn079 [PubMed: 18940959]

Crews FT, Qin L, Sheedy D, Vetreno RP, Zou J. High mobility group box 1/Toll-like receptor danger signaling increases brain neuroimmune activation in alcohol dependence. Biological Psychiatry. 2013; 73:602-612. DOI: 10.1016/j.biopsych.2012.09.030 [PubMed: 23206318]

Crews FT, Vetreno RP. Neuroimmune basis of alcoholic brain damage. International Review of Neurobiology. 2014; 118:315-357. DOI: 10.1016/B978-0-12-801284-0.00010-5 [PubMed: 25175868]

Crews FT, Zou J, Qin L. Induction of innate immune genes in brain create the neurobiology of addiction. Brain, Behavior, and Immunity. 2011; 25(Suppl 1):S4-S12. DOI: 10.1016/j.bbi. 2011.03.003

Cui C, Shurtleff D, Harris RA. Neuroimmune mechanisms of alcohol and drug addiction. International Review of Neurobiology. 2014; 118:1-12. DOI: 10.1016/B978-0-12-801284-0.00001-4 [PubMed: 25175859]

David S, Kroner A. Repertoire of microglial and macrophage responses after spinal cord injury. Nature Reviews Neuroscience. 2011; 12:388-399. DOI: 10.1038/nrn3053 [PubMed: 21673720]

Davis RL, Syapin PJ. Ethanol increases nuclear factor-kappa B activity in human astroglial cells. Neuroscience Letters. 2004; 371:128-132. DOI: 10.1016/j.neulet.2004.08.051 [PubMed: 15519742]

de la Monte SM, Kril JJ. Human alcohol-related neuropathology. Acta Neuropathologica. 2014; 127:71-90. DOI: 10.1007/s00401-013-1233-3 [PubMed: 24370929]

Dennis CV, Sheahan PJ, Graeber MB, Sheedy DL, Kril JJ, Sutherland GT. Microglial proliferation in the brain of chronic alcoholics with hepatic encephalopathy. Metabolic Brain Disease. 2013; 29:1027-1039. DOI: 10.1007/s11011-013-9469-0 [PubMed: 24346482]

Fernandez-Lizarbe S, Montesinos J, Guerri C. Ethanol induces TLR4/TLR2 association, triggering an inflammatory response in microglial cells. Journal of Neurochemistry. 2013; 126:261-273. DOI: 10.1111/jnc.12276 [PubMed: 23600947]

Fernandez-Lizarbe S, Pascual M, Guerri C. Critical role of TLR4 response in the activation of microglia induced by ethanol. Journal of Immunology. 2009; 183:4733-4744. DOI: 10.4049/ jimmunol.0803590

Flatscher-Bader T, van der Brug M, Hwang JW, Gochee PA, Matsumoto I, Niwa S, et al. Alcoholresponsive genes in the frontal cortex and nucleus accumbens of human alcoholics. Journal of Neurochemistry. 2005; 93:359-370. DOI: 10.1111/j.1471-4159.2004.03021.x [PubMed: 15816859]

Ford AL, Goodsall AL, Hickey WF, Sedgwick JD. Normal adult ramified microglia separated from other central nervous system macrophages by flow cytometric sorting. Phenotypic differences defined and direct ex vivo antigen presentation to myelin basic protein-reactive CD4+ T cells compared. Journal of Immunology. 1995; 154:4309-4321.

Frank MG, Baratta MV, Sprunger DB, Watkins LR, Maier SF. Microglia serve as a neuroimmune substrate for stress-induced potentiation of CNS pro-inflammatory cytokine responses. Brain, Behavior, and Immunity. 2007; 21:47-59. DOI: 10.1016/j.bbi.2006.03.005

Frank MG, Weber MD, Fonken LK, Hershman SA, Watkins LR, Maier SF. The redox state of the alarmin HMGB1 is a pivotal factor in neuroinflammatory and microglial priming: A role for the NLRP3 inflammasome. Brain, Behavior, and Immunity. 2016; 55:215-224. DOI: 10.1016/j.bbi. 2015.10.009 
Frank MG, Wieseler-Frank JL, Watkins LR, Maier SF. Rapid isolation of highly enriched and quiescent microglia from adult rat hippocampus: immunophenotypic and functional characteristics. Journal of Neuroscience Methods. 2006; 151:121-130. DOI: 10.1016/j.jneumeth. 2005.06.026 [PubMed: 16125247]

Gano A, Doremus-Fitzwater TL, Deak T. Sustained alterations in neuroimmune gene expression after daily, but not intermittent, alcohol exposure. Brain Research. 2016; 1646:62-72. DOI: 10.1016/ j.brainres.2016.05.027 [PubMed: 27208497]

Goral J, Karavitis J, Kovacs EJ. Exposure-dependent effects of ethanol on the innate immune system. Alcohol. 2008; 42:237-247. DOI: 10.1016/j.alcohol.2008.02.003 [PubMed: 18411007]

Graeber MB. Changing face of microglia. Science. 2010; 330:783-788. DOI: 10.1126/science. 1190929 [PubMed: 21051630]

Grant BF, Goldstein RB, Saha TD, Chou SP, Jung J, Zhang H, et al. Epidemiology of DSM-5 Alcohol Use Disorder: Results From the National Epidemiologic Survey on Alcohol and Related Conditions III. JAMA Psychiatry. 2015; 72:757-766. DOI: 10.1001/jamapsychiatry.2015.0584 [PubMed: 26039070]

Guillemin GJ, Brew BJ. Microglia, macrophages, perivascular macrophages, and pericytes: a review of function and identification. Journal of Leukocyte Biology. 2004; 75:388-397. DOI: 10.1189/jlb. 0303114 [PubMed: 14612429]

Haorah J, Knipe B, Leibhart J, Ghorpade A, Persidsky Y. Alcohol-induced oxidative stress in brain endothelial cells causes blood-brain barrier dysfunction. Journal of Leukocyte Biology. 2005; 78:1223-1232. DOI: 10.1189/jlb.0605340 [PubMed: 16204625]

He J, Crews FT. Increased MCP-1 and microglia in various regions of the human alcoholic brain. Experimental Neurology. 2008; 210:349-358. DOI: 10.1016/j.expneurol.2007.11.017 [PubMed: 18190912]

Hu X, Li P, Guo Y, Wang H, Leak RK, Chen S, et al. Microglia/macrophage polarization dynamics reveal novel mechanism of injury expansion after focal cerebral ischemia. Stroke. 2012; 43:30633070. DOI: 10.1161/STROKEAHA.112.659656 [PubMed: 22933588]

Hunt WA. Are binge drinkers more at risk of developing brain damage? Alcohol. 1993; 10:559-561. [PubMed: 8123218]

Hynes RO. Integrins: versatility, modulation, and signaling in cell adhesion. Cell. 1992; 69:11-25. [PubMed: 1555235]

Jin X, Ishii H, Bai Z, Itokazu T, Yamashita T. Temporal changes in cell marker expression and cellular infiltration in a controlled cortical impact model in adult male C57BL/6 mice. PLoS One. 2012; 7:e41892.doi: 10.1371/journal.pone.0041892 [PubMed: 22911864]

Kelso ML, Liput DJ, Eaves DW, Nixon K. Upregulated vimentin suggests new areas of neurodegeneration in a model of an alcohol use disorder. Neuroscience. 2011; 197:381-393. DOI: 10.1016/j.neuroscience.2011.09.019 [PubMed: 21958862]

Kigerl KA, Gensel JC, Ankeny DP, Alexander JK, Donnelly DJ, Popovich PG. Identification of two distinct macrophage subsets with divergent effects causing either neurotoxicity or regeneration in the injured mouse spinal cord. The Journal of Neuroscience. 2009; 29:13435-13444. DOI: 10.1523/JNEUROSCI.3257-09.2009 [PubMed: 19864556]

Lalancette-Hébert M, Gowing G, Simard A, Weng YC, Kriz J. Selective ablation of proliferating microglial cells exacerbates ischemic injury in the brain. The Journal of Neuroscience. 2007; 27:2596-2605. DOI: 10.1523/JNEUROSCI.5360-06.2007 [PubMed: 17344397]

Lambertsen KL, Clausen BH, Babcock AA, Gregersen R, Fenger C, Nielsen HH, et al. Microglia protect neurons against ischemia by synthesis of tumor necrosis factor. The Journal of Neuroscience. 2009; 29:1319-1330. DOI: 10.1523/JNEUROSCI.5505-08.2009 [PubMed: 19193879]

Liu J, Lewohl JM, Harris RA, Iyer VR, Dodd PR, Randall PK, et al. Patterns of gene expression in the frontal cortex discriminate alcoholic from nonalcoholic individuals. Neuropsychopharmacology. 2006; 31:1574-1582. DOI: 10.1038/sj.npp.1300947 [PubMed: 16292326]

Majchrowicz E. Induction of physical dependence upon ethanol and the associated behavioral changes in rats. Psychopharmacology. 1975; 43:245-254. 
Marshall SA, Geil CR, Nixon K. Prior Binge Ethanol Exposure Potentiates the Microglial Response in a Model of Alcohol-Induced Neurodegeneration. Brain Sciences. 2016; 6 pii: E16. doi: 10.3390/ brainsci6020016

Marshall SA, McClain JA, Kelso ML, Hopkins DM, Pauly JR, Nixon K. Microglial activation is not equivalent to neuroinflammation in alcohol-induced neurodegeneration: The importance of microglia phenotype. Neurobiology of Diseases. 2013; 54:239-251. DOI: 10.1016/j.nbd. 2012.12.016

McClain JA, Morris SA, Deeny MA, Marshall SA, Hayes DM, Kiser ZM, et al. Adolescent binge alcohol exposure induces long-lasting partial activation of microglia. Brain, Behavior, and Immunity. 2011; 25(Suppl 1):S120-128. DOI: 10.1016/j.bbi.2011.01.006

Mechtcheriakov S, Brenneis C, Egger K, Koppelstaetter F, Schocke M, Marksteiner J. A widespread distinct pattern of cerebral atrophy in patients with alcohol addiction revealed by voxel-based morphometry. Journal of Neurology, Neurosurgery, and Psychiatry. 2007; 78:610-614. DOI: 10.1136/jnnp.2006.095869

Mikita J, Dubourdieu-Cassagno N, Deloire MS, Vekris A, Biran M, Raffard G, et al. Altered M1/M2 activation patterns of monocytes in severe relapsing experimental rat model of multiple sclerosis. Amelioration of clinical status by M2 activated monocyte administration. Multiple Sclerosis. 2011; 17:2-15. DOI: 10.1177/1352458510379243 [PubMed: 20813772]

Morioka T, Kalehua AN, Streit WJ. Progressive expression of immunomolecules on microglial cells in rat dorsal hippocampus following transient forebrain ischemia. Acta Neuropathologica. 1992; 83:149-157. [PubMed: 1557947]

Morris SA, Kelso ML, Liput DJ, Marshall SA, Nixon K. Similar withdrawal severity in adolescents and adults in a rat model of alcohol dependence. Alcohol. 2010; 44:89-98. DOI: 10.1016/ j.alcohol.2009.10.017 [PubMed: 20113877]

NIAAA. [Accessed 01/10/2017] National Institute on Alcohol Abuse and Alcoholism webpage. 2017. https://www.niaaa.nih.gov/alcohol-health/overview-alcohol-consumption/moderate-binge-drinking

Nimmerjahn A, Kirchhoff F, Helmchen F. Resting microglial cells are highly dynamic surveillants of brain parenchyma in vivo. Science. 2005; 308:1314-1318. DOI: 10.1126/science.1110647 [PubMed: 15831717]

Nixon K, Kim DH, Potts EN, He J, Crews FT. Distinct cell proliferation events during abstinence after alcohol dependence: microglia proliferation precedes neurogenesis. Neurobiology of Disease. 2008; 31:218-229. DOI: 10.1016/j.nbd.2008.04.009 [PubMed: 18585922]

NRC. Guide for the Care and Use of Laboratory Animals. Washington, D.C: The National Academies Press; 1996.

Pascual M, Blanco AM, Cauli O, Miñarro J, Guerri C. Intermittent ethanol exposure induces inflammatory brain damage and causes long-term behavioural alterations in adolescent rats. The European Journal of Neuroscience. 2007; 25:541-550. DOI: 10.1111/j.1460-9568.2006.05298.x [PubMed: 17284196]

Perry VH, Holmes C. Microglial priming in neurodegenerative disease. Nature Reviews Neurology. 2014; 10:217-224. DOI: 10.1038/nrneurol.2014.38 [PubMed: 24638131]

Pfefferbaum A, Lim KO, Zipursky RB, Mathalon DH, Rosenbloom MJ, Lane B, et al. Brain gray and white matter volume loss accelerates with aging in chronic alcoholics: a quantitative MRI study. Alcoholism: Clinical and Experimental Research. 1992; 16:1078-1089.

Ponomarev ED, Veremeyko T, Barteneva N, Krichevsky AM, Weiner HL. MicroRNA-124 promotes microglia quiescence and suppresses EAE by deactivating macrophages via the C/EBP-a-PU.1 pathway. Nature Medicine. 2011; 17:64-70. DOI: 10.1038/nm.2266

Qin L, He J, Hanes RN, Pluzarev O, Hong JS, Crews FT. Increased systemic and brain cytokine production and neuroinflammation by endotoxin following ethanol treatment. Journal of Neuroinflammation. 2008; 5:10.doi: 10.1186/1742-2094-5-10 [PubMed: 18348728]

Raivich G, Bohatschek M, Kloss CU, Werner A, Jones LL, Kreutzberg GW. Neuroglial activation repertoire in the injured brain: graded response, molecular mechanisms and cues to physiological function. Brain Research Brain Research Reviews. 1999; 30:77-105. [PubMed: 10407127]

Ransohoff RM, Perry VH. Microglial physiology: unique stimuli, specialized responses. Annual Review of Immunology. 2009; 27:119-145. DOI: 10.1146/annurev.immunol.021908.132528 
Robinson G, Most D, Ferguson LB, Mayfield J, Harris RA, Blednov YA. Neuroimmune pathways in alcohol consumption: evidence from behavioral and genetic studies in rodents and humans. International Review of Neurobiology. 2014; 118:13-39. DOI: 10.1016/ B978-0-12-801284-0.00002-6 [PubMed: 25175860]

Stirling DP, Yong VW. Dynamics of the inflammatory response after murine spinal cord injury revealed by flow cytometry. Journal of Neuroscience Research. 2008; 86:1944-1958. DOI: 10.1002/jnr.21659 [PubMed: 18438914]

Suk K. Microglial signal transduction as a target of alcohol action in the brain. Current Neurovascular Research. 2007; 4:131-142. [PubMed: 17504211]

Sullivan EV, Pfefferbaum A. Neurocircuitry in alcoholism: a substrate of disruption and repair. Psychopharmacology (Berl). 2005; 180:583-594. DOI: 10.1007/s00213-005-2267-6 [PubMed: 15834536]

Sutherland GT, Sheahan PJ, Matthews J, Dennis CV, Sheedy DS, McCrossin T, et al. The effects of chronic alcoholism on cell proliferation in the human brain. Experimental Neurology. 2013; 247:9-18. DOI: 10.1016/j.expneurol.2013.03.020 [PubMed: 23541433]

Szalay G, Martinecz B, Lénárt N, Környei Z, Orsolits B, Judák L, et al. Microglia protect against brain injury and their selective elimination dysregulates neuronal network activity after stroke. Nature Communications. 2016; 7:11499.doi: 10.1038/ncomms11499

Turrin NP, Rivest S. Tumor necrosis factor alpha but not interleukin 1 beta mediates neuroprotection in response to acute nitric oxide excitotoxicity. The Journal of Neuroscience. 2006; 26:143-151. DOI: 10.1523/JNEUROSCI.4032-05.2006 [PubMed: 16399681]

Vallés SL, Blanco AM, Pascual M, Guerri C. Chronic ethanol treatment enhances inflammatory mediators and cell death in the brain and in astrocytes. Brain Pathology. 2004; 14:365-371. [PubMed: 15605983]

Vetreno RP, Crews FT. Adolescent binge drinking increases expression of the danger signal receptor agonist HMGB1 and Toll-like receptors in the adult prefrontal cortex. Neuroscience. 2012; 226:475-488. DOI: 10.1016/j.neuroscience.2012.08.046 [PubMed: 22986167]

Vetreno RP, Qin L, Crews FT. Increased receptor for advanced glycation end product expression in the human alcoholic prefrontal cortex is linked to adolescent drinking. Neurobiology of Disease. 2013; 59:52-62. DOI: 10.1016/j.nbd.2013.07.002 [PubMed: 23867237]

Wang X, Chu G, Yang Z, Sun Y, Zhou H, Li M, et al. Ethanol directly induced HMGB1 release through NOX2/NLRP1 inflammasome in neuronal cells. Toxicology. 2015; 334:104-110. DOI: 10.1016/j.tox.2015.06.006 [PubMed: 26079697]

Ward RJ, Colivicchi MA, Allen R, Schol F, Lallemand F, de Witte P, et al. Neuro-inflammation induced in the hippocampus of 'binge drinking' rats may be mediated by elevated extracellular glutamate content. Journal of Neurochemisty. 2009; 111:1119-1128. DOI: 10.1111/j. 1471-4159.2009.06389.x

Weber MD, Frank MG, Tracey KJ, Watkins LR, Maier SF. Stress induces the danger-associated molecular pattern HMGB-1 in the hippocampus of male Sprague Dawley rats: a priming stimulus of microglia and the NLRP3 inflammasome. The Journal of Neuroscience. 2015; 35:316-324. DOI: 10.1523/JNEUROSCI.3561-14.2015 [PubMed: 25568124]

Yenari MA, Kauppinen TM, Swanson RA. Microglial activation in stroke: therapeutic targets. Neurotherapeutics. 2010; 7:378-391. DOI: 10.1016/j.nurt.2010.07.005 [PubMed: 20880502]

Zahr NM, Luong R, Sullivan EV, Pfefferbaum A. Measurement of serum, liver, and brain cytokine induction, thiamine levels, and hepatopathology in rats exposed to a 4-day alcohol binge protocol. Alcoholism: Clinical and Experimental Research. 2010; 34:1858-1870. DOI: 10.1111/j. 1530-0277.2010.01274.x

Zhang B, Gensel JC. Is neuroinflammation in the injured spinal cord different than in the brain? Examining intrinsic differences between the brain and spinal cord. Experimental Neurology. 2014; 258:112-120. DOI: 10.1016/j.expneurol.2014.04.007 [PubMed: 25017892] 


\section{Highlights}

- Identifying microglia phenotypes is critical to understanding the role of microglia in AUDs.

- Flow cytometry of isolated microglia was used for the first time in alcohol research.

- $\quad$ Four-day binge alcohol exposure transiently increases M1 and M2 populations of microglia. 
A
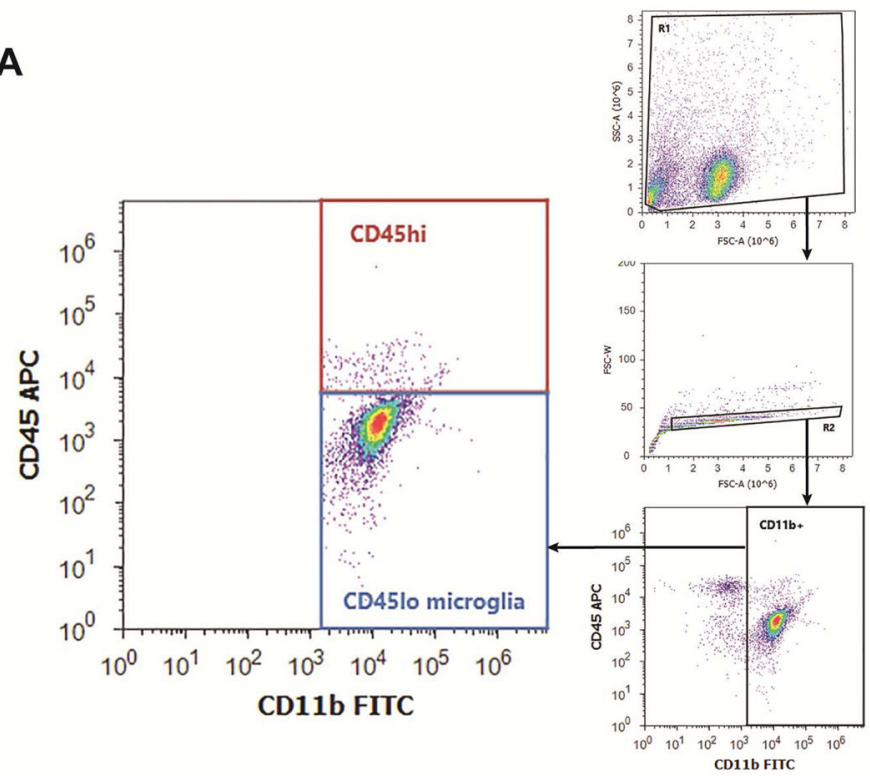

B Hippocampus

C
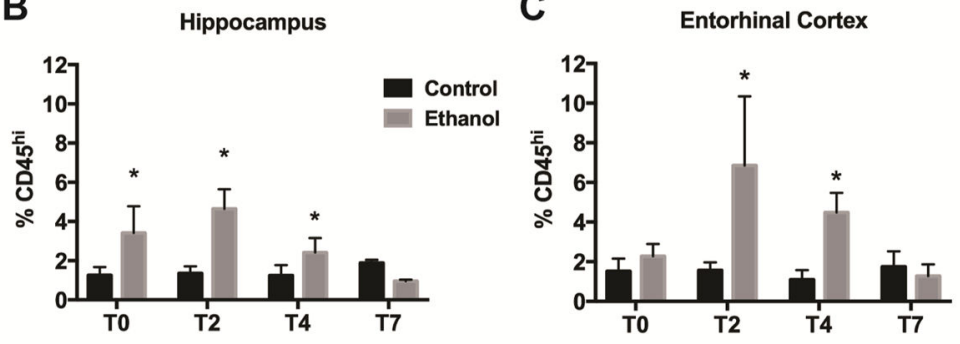

D

Hippocampus

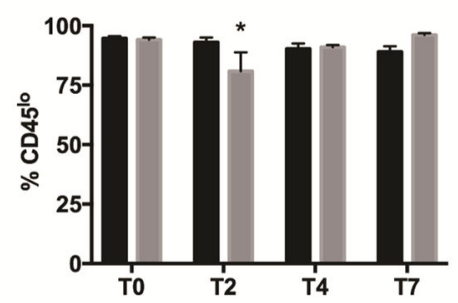

E

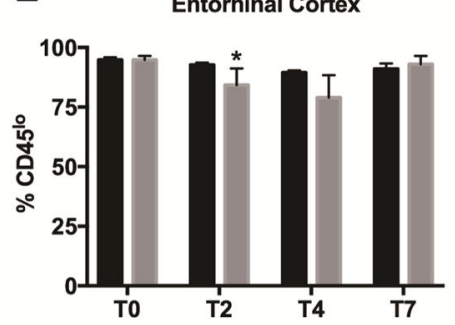

Fig. 1. Two populations of CD11 ${ }^{+}$myeloid cells were identified from adult rat brains after a four-day binge alcohol exposure by flow cytometry

At 0, 2, 4, and 7 days after the last dose of diet (i.e., T0, T2, T4, and T7), microglia were isolated from hippocampal and entorhinal cortex homogenates through Percoll density gradient centrifugation. Cells were labeled with microglia surface antigens and analyzed by flow cytometry. A. Debris and aggregates were eliminated from the analysis by forward- and side-scatter characteristics (small plots). Myeloid cells identified as $\mathrm{CD} 11 \mathrm{~b}^{+}$singlets were further divided into $\mathrm{CD} 11 \mathrm{~b}^{+} \mathrm{CD} 45^{\text {lo }}$ microglia (blue box) and a small $\mathrm{CD} 11 \mathrm{~b}^{+} \mathrm{CD} 45^{\mathrm{hi}}$ cell subpopulation (red box). B-E. The relative frequencies of CD11b ${ }^{+} \mathrm{CD} 45^{\text {hi }}$ cells $(\mathbf{B} \& \mathbf{C})$ and $\mathrm{CD} 11 \mathrm{~b}^{+} \mathrm{CD} 45^{\text {lo }}$ microglia (D \& E) varied significantly between control and alcohol-exposed rat hippocampus (B \& D) and entorhinal cortex $(\mathbf{C} \& \mathbf{E}) . * p<0.05$ versus control. 
A

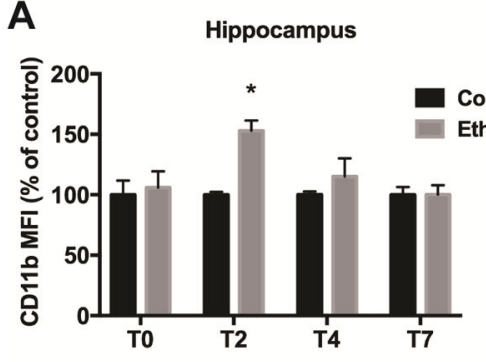

C

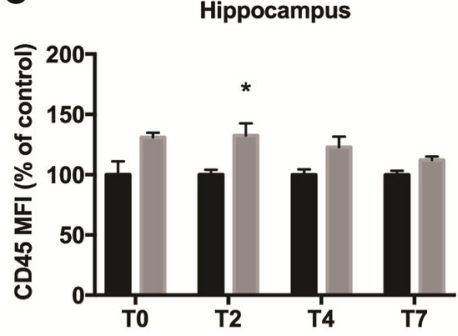

B Entorhinal Cortex

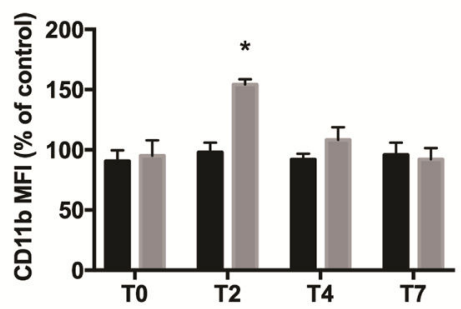

D

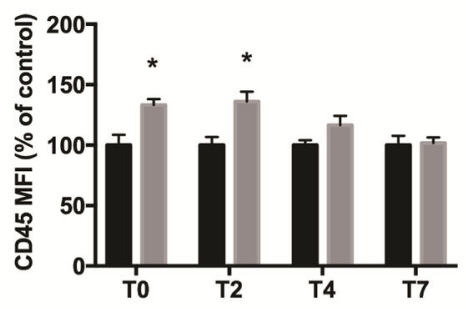

Fig. 2. Mean fluorescent intensity (MFI) of CD11b and CD45 expression on $\mathrm{CD}_{11 b}{ }^{+} \mathrm{CD}^{\mathrm{lo}} 5^{\mathrm{lo}}$ microglia

A-D. Data presented show MFI of CD11b (A \& B) and CD45 (C \& D) on CD11b ${ }^{+}$CD 45 $5^{\text {lo }}$ microglia isolated from control and alcohol-exposed rat hippocampus (A \& $\mathbf{C})$ and entorhinal cortex (B \& D) as a percent of control. $* p<0.05$ versus respective control. 
A
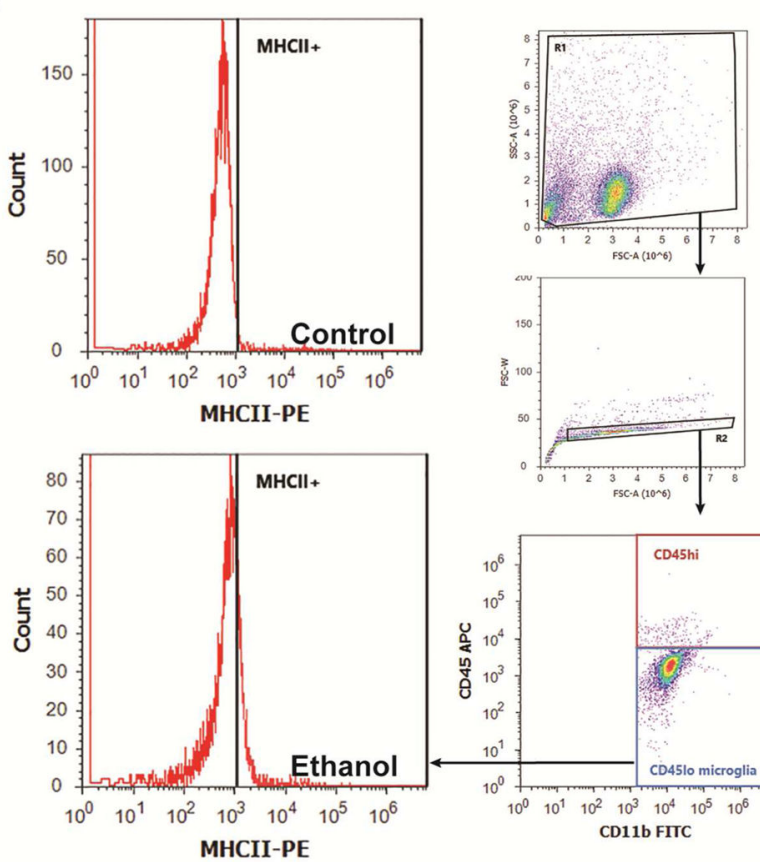

B

Hippocampus
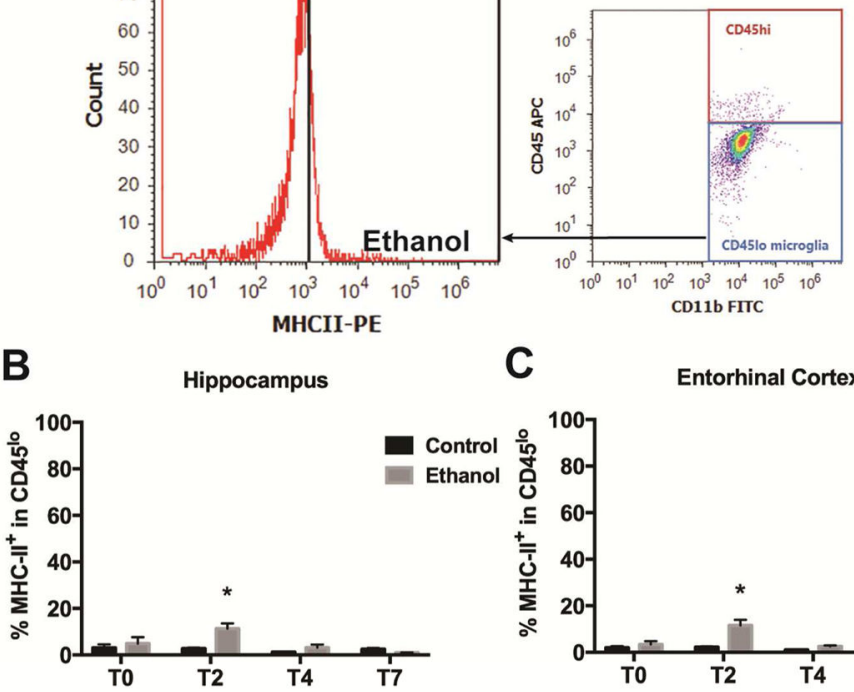

C

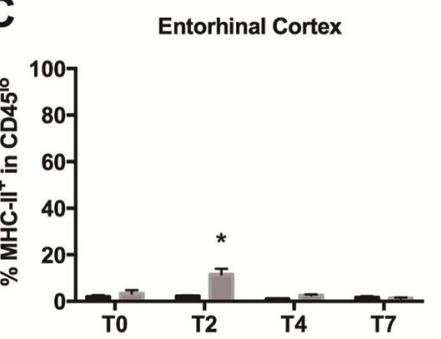

D

Hippocampus

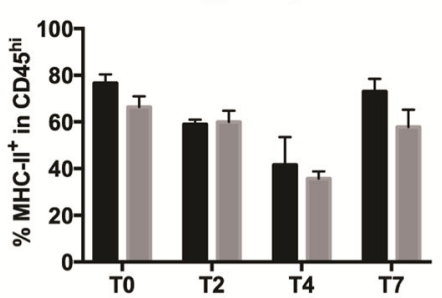

E
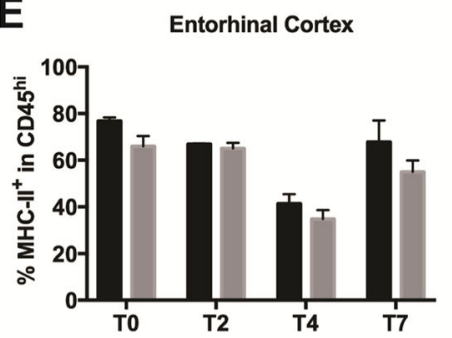

Fig. 3. Increased expression of MHC-II on $\mathrm{CD} 11 \mathrm{~b}^{+} \mathrm{CD}^{2} 5^{10}$ cells after a four-day binge alcohol exposure

A. $\mathrm{MHC} \mathrm{II}^{+}$cells were enumerated in $\mathrm{CD} 11 \mathrm{~b}^{+} \mathrm{CD} 45^{\text {lo }}$ microglia (blue box) and $\mathrm{CD} 11 \mathrm{~b}^{+} \mathrm{CD} 45^{\mathrm{hi}}$ cells (red box) after any remaining myelin debris and aggregates were eliminated by exclusion gates based on scatter characteristics (small plots). B-E. The percentage of $\mathrm{MHC} \mathrm{II}^{+}$cells within $\mathrm{CD} 11 \mathrm{~b}^{+} \mathrm{CD} 45^{\mathrm{lo}}$ microglia $(\mathbf{B} \& \mathbf{C})$ and $\mathrm{CD} 11 \mathrm{~b}^{+} \mathrm{CD} 45^{\text {hi }}$ cells $(\mathbf{D} \& \mathbf{E})$ varied significantly between control and alcohol-exposed rat hippocampus (B $\boldsymbol{\&} \mathbf{D})$ and entorhinal cortex $(\mathbf{C} \& \mathbf{E}) .{ }^{*} p<0.05$ versus respective control. 


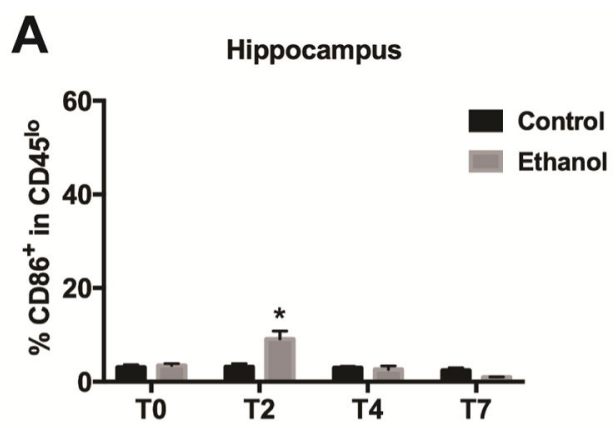

B Entorhinal Cortex

C

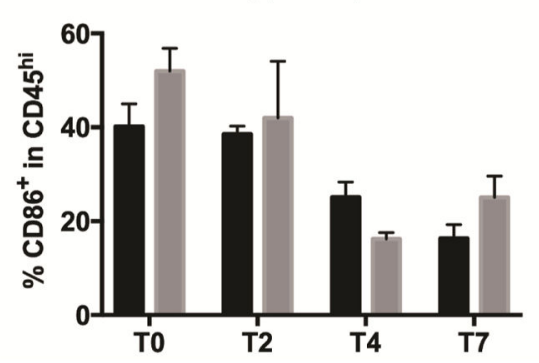

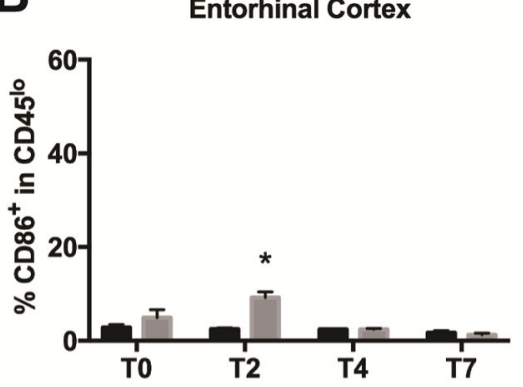

D



Fig. 4. Increased expression of $\mathrm{CD86}$ on $\mathrm{CD}_{11 \mathrm{~b}^{+}} \mathrm{CD}^{\mathrm{i}} 5^{\mathrm{lo}}$ cells after a four-day binge alcohol exposure

A-D. The percentage of $\mathrm{CD} 86^{+}$cells within $\mathrm{CD} 11 \mathrm{~b}^{+} \mathrm{CD} 45^{\mathrm{lo}}$ microglia $(\mathbf{A} \& \mathbf{B})$ and $\mathrm{CD} 11 \mathrm{~b}^{+} \mathrm{CD} 45^{\text {hi }}$ cells $(\mathbf{C} \& \mathbf{D})$ varied significantly between control and alcohol-exposed rat hippocampus (A \& C) and entorhinal cortex (B \& D). $* p<0.05$ versus respective control. 




B Entorhinal Cortex

C

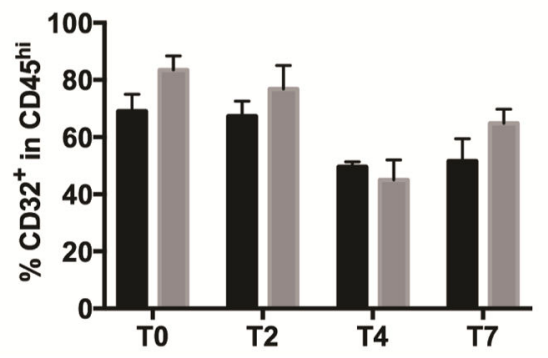

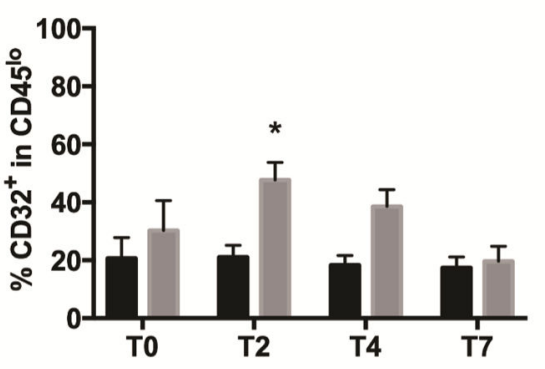

D Entorhinal Cortex

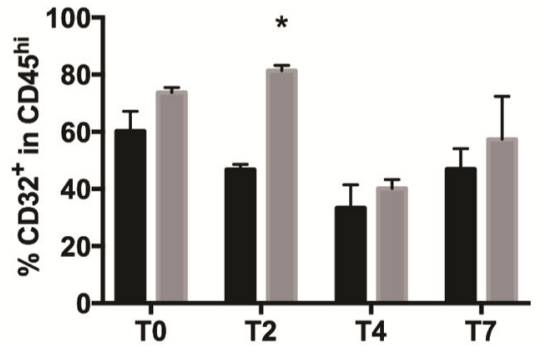

Fig. 5. Increased expression of $\mathrm{CD} 32$ on $\mathrm{CD}_{11 \mathrm{~b}^{+}} \mathrm{CD}^{2} 5^{10}$ cells after a four-day binge alcohol exposure

A-D. The percentage of CD $32^{+}$cells within $\mathrm{CD} 11 \mathrm{~b}^{+} \mathrm{CD} 45^{\mathrm{lo}}$ microglia $(\mathbf{A} \& \mathbf{B})$ and $\mathrm{CD} 11 \mathrm{~b}^{+} \mathrm{CD} 45^{\text {hi }}$ cells $(\mathbf{C} \& \mathbf{D})$ varied significantly between control and alcohol-exposed rat hippocampus (A \& C) and entorhinal cortex (B \& D). * $p<0.05$ versus respective control. 
B Entorhinal Cortex

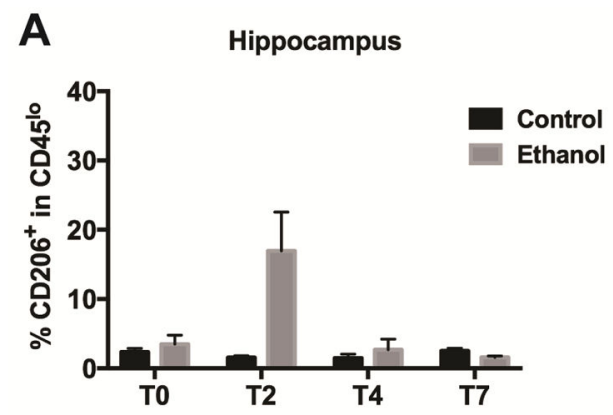

A

C

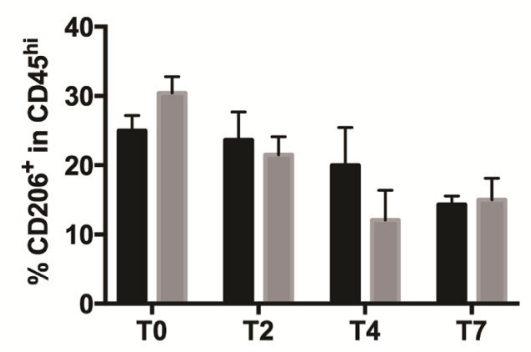

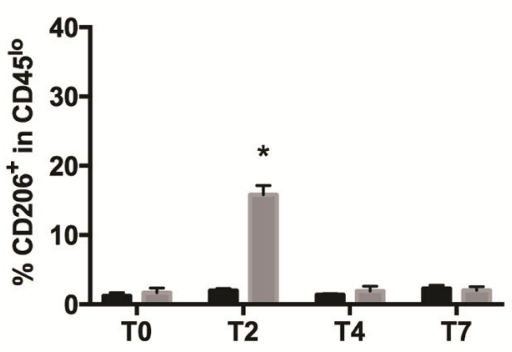

D



Fig. 6. Increased expression of $\mathrm{CD206}$ on $\mathrm{CD} 1 \mathrm{~b}^{+} \mathrm{CD}^{\mathrm{C}} 5^{\mathrm{lo}}$ cells after four-day binge alcohol exposure

A-D. The percentage of CD206 ${ }^{+}$cells within $\mathrm{CD} 11 \mathrm{~b}^{+} \mathrm{CD} 45^{\text {lo }}$ microglia $(\mathbf{A} \& \mathbf{B})$ and $\mathrm{CD} 11 \mathrm{~b}^{+} \mathrm{CD} 45^{\text {hi }}$ cells $(\mathbf{C} \& \mathbf{D})$ varied significantly between control and alcohol-exposed rat hippocampus (A \& C) and entorhinal cortex (B \& D). * $p<0.05$ versus respective control. 

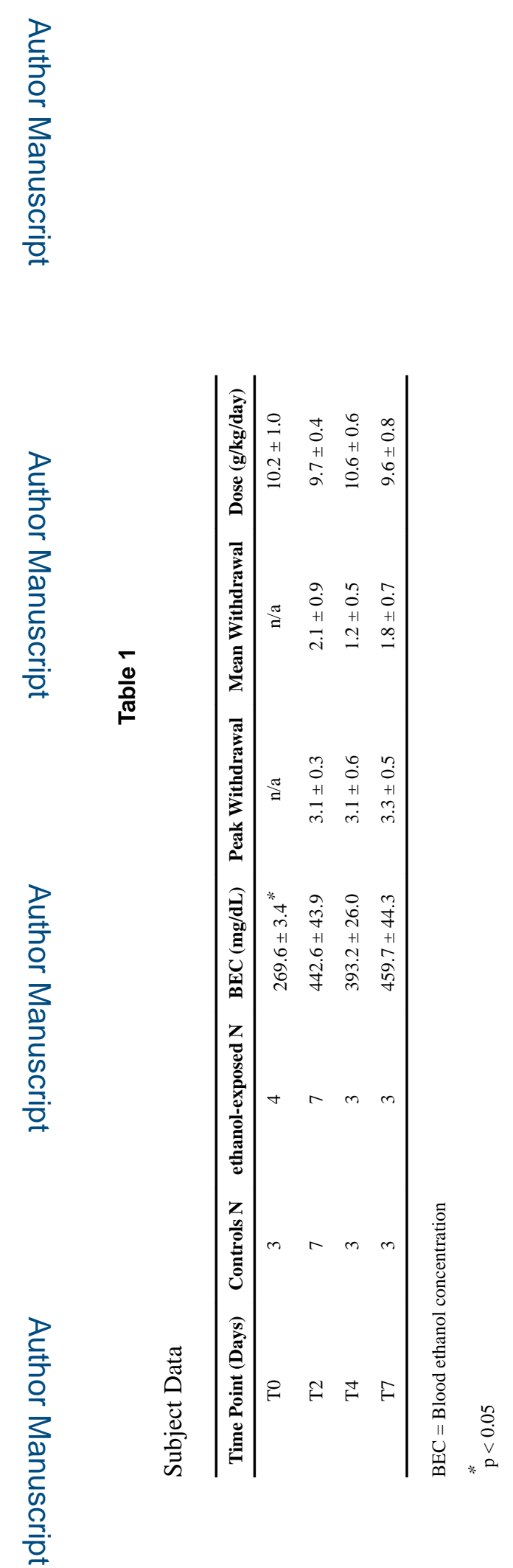

Alcohol. Author manuscript; available in PMC 2018 August 01. 